\title{
Satellite remote sensing data and their interpretations for geothermal applications: A case study on the Ngada District, central Flores, Indonesia
}

\author{
Minoru URAI ${ }^{1}$, Hirofumi MURAOKA ${ }^{2}$ and Asnawir NASUTION ${ }^{3}$
}

\begin{abstract}
Minoru URAi, Hirofumi MuraOKa and Asnawir NASUTiOn (2002) Satellite remote sensing data and their interpretations for geothermal applications: A case study on the Ngada District, central Flores, Indonesia. Bull. Geol. Surv. Japan, vol. 53 (2/3), p. 99-108, 10 figs., 4 tables.
\end{abstract}

\begin{abstract}
A remote sensing survey was conducted in the Ngada District for geothermal exploration using JERS-1 SAR and OPS, and ASTER VNIR and TIR data. As a result, many small volcanic cones, which have diameters less than $5 \mathrm{~km}$, are seen near the Bajawa in the SAR image. Some volcanic cones are aligned along the north-south direction. Since the SAR has allweather observation capability, it provides us with details of the volcanic features in the study area, where it is difficult to obtain cloud-free images using optical sensors. Volcanic features are not as obvious in the OPS image compared with the SAR image because of the high sun elevation angle in tropical areas. A small high temperature anomaly is found at the Nage geothermal area using ASTER TIR, which is a new spaceborne sensor having a high spatial resolution. These results demonstrate the advantages and limitations of satellite remote sensing survey for geothermal applications.
\end{abstract}

\section{Introduction}

Remote sensing can contribute to geothermal studies and exploration by detecting surface thermal anomalies by using of thermal infrared imagery, mapping lineaments that are conduits for geothermal fluids, depicting the regional volcanic framework, and delineating hydrothermal altered area by the use of short-wave infrared regions (Yamaguchi et al., 1992a).

Indonesia comprises more than 17,000 islands stretching along the equator from the Malaysian mainland to New Guinea. Indonesia has the fifth largest population in the world. About $60 \%$ of Indonesians live on Java Island, which has less than $7 \%$ of the country's total area. The Indonesian government plans to construct roads, communication lines, city water systems and electric power plants in remote islands for economic growth and educational promotion. As a part of this plan, Indonesian government is promoting the Regional Electrification Plan using hydropower, geothermal energy and other sources.

Nusa Tenggara Timur consists of Flores, Alor,

\footnotetext{
${ }^{1}$ Institute of Geoscience, GSJ

${ }^{2}$ Institute for Geo-Resources and Environment, GSJ

${ }^{3}$ Directorate of Volcanology and Geological Hazard

Mitigation JI. Diponegoro No.57, Bandung, 40122 Indonesia
}

Lembata, Komodo, West Timor and other islands. Many active volcanoes and abundant geothermal resources are expected in this region. The Directorate General of Geology and Mineral Resources of Indonesia, New Energy and Industrial Technology Development Organization and Geological Survey of Japan started a joint research study entitled "Research Cooperation Project on the Exploration of Small-scale Geothermal Resources in the Eastern Part of Indonesia" in 1997 (Muraoka and Uchida, 1999). As the first step of the project, a remote sensing survey has been conducted for regional geological studies in five promising geothermal fields (Urai et al., 1999). The next step, Urai et al. (2000) is concentrated on the remote sensing survey in the Ngada District. In this paper, we present JERS-1 SAR and OPS, and ASTER VNIR TIR imagery of the Ngada District and their interpretations.

\section{Outline of the study area}

The study area, shown in Fig. 1, is located on central Flores Island. Bajawa, the capital of the Ngada District, is surrounded by active volcanoes, which are associated with subduction or collision tectonics between the Australian plate and Lesser Sunda-Banda arc (Muraoka et al., 1999). A few areas of steaming ground and many hot springs are Keywords: remote sensing, SAR, OPS, ASTER, geothermal, Flores, Indonesia 


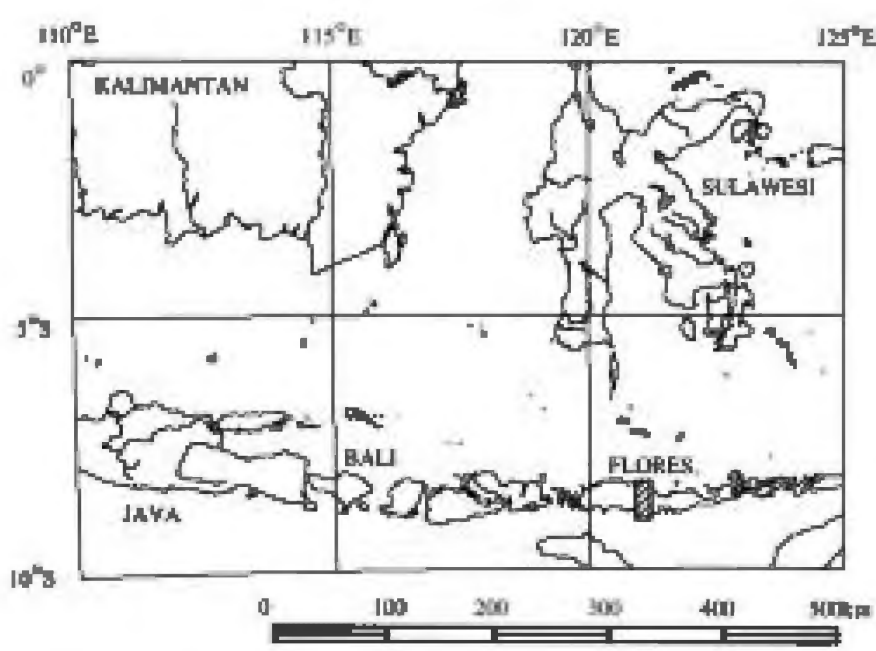

Fig. 1 Location of the study area.

Hatched area indicates the study area.

found in the southern part of the study area (Muraoka et al., 1999; Takahashi et al., 1999).

The largest hot spring is found in the Nage geothermal area, which is $8 \mathrm{~km}$ southwest of Bajawa. The steaming field's area is $200 \mathrm{~m}$ by $500 \mathrm{~m}$ along the Wae Bana River and geothermal waters more than $75{ }^{\circ} \mathrm{C}$ gush out from the springs (Takahashi et al., 2000). The total flow rate is more than 30 tons/ $\min$.

\section{Satellite image interpretations}

\subsection{JERS-1 SAR image}

The JERS-1 (Japanese Earth Resources Satellite 1) was launched into a sun synchronous orbit on February 11, 1992, and ended its mission on October 12 , 1998. The JERS-1 was equipped with the Synthetic Aperture Rader (SAR) and the Optical Sensors (OPS) instruments (Yamaguchi et al., 1992b). Table 1 shows the major characteristics of JERS-1 sensors. The SAR has all-weather observation capabil-
Table 1 The major characteristic of JERS-1 sensors (Yamaguchi et al., 1992b).

* Transmitting power was reduced to $325 \mathrm{~W}$ due to the problem of electric discharge in the antenna cable (Takata, 1995).

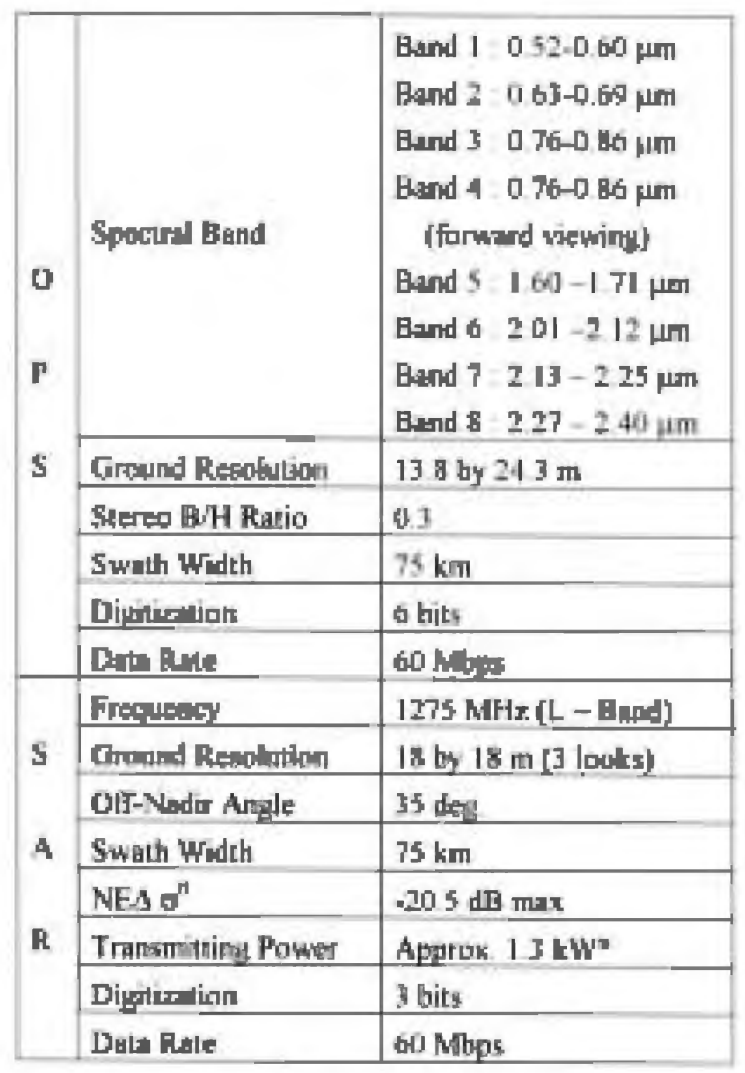

ity, and it provides valuable images for tropical regions, where it is difficult to obtain cloud-free images with optical sensors.

Figure 2 shows the SAR mosaic image of western Flores Island, which is combined with five SAR scenes acquired from adjacent satellite paths from January 1996 to September 1998. Many volcanic features such as calderas, craters and crater lakes are

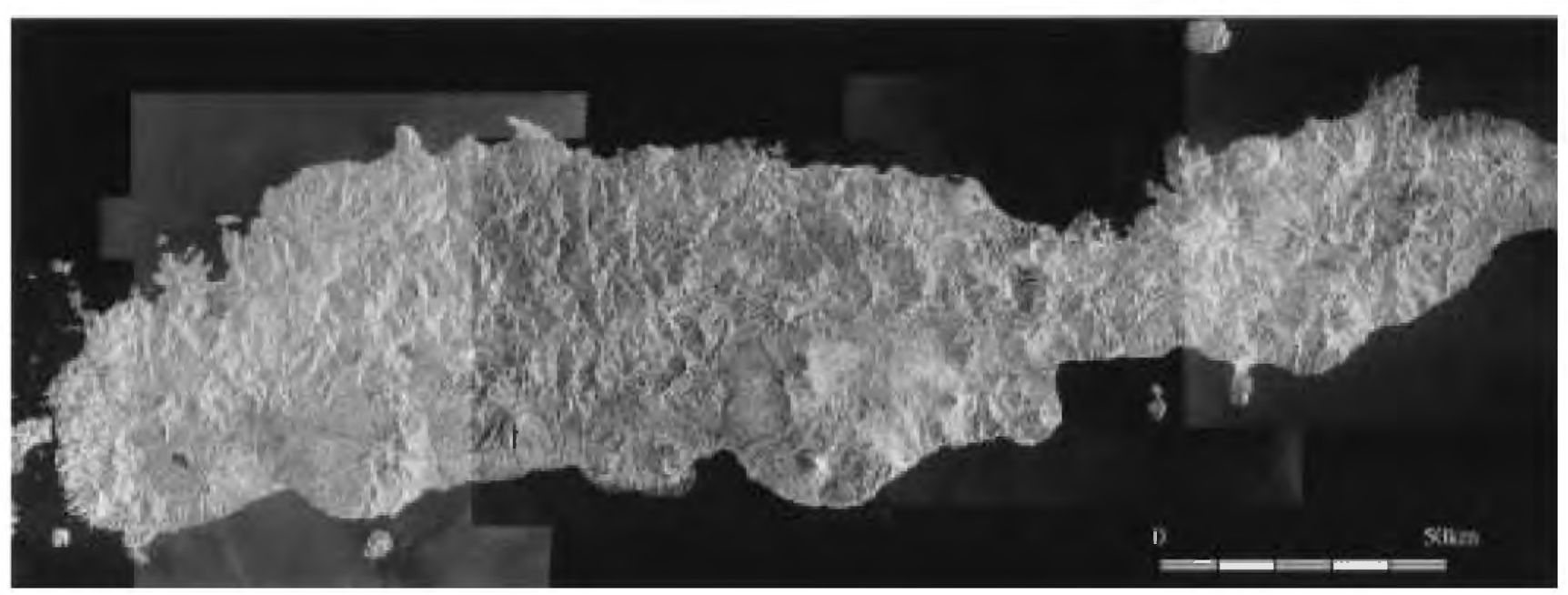

Fig. 2 SAR image of the western Flores Island (Copyright METI/NASDA). 


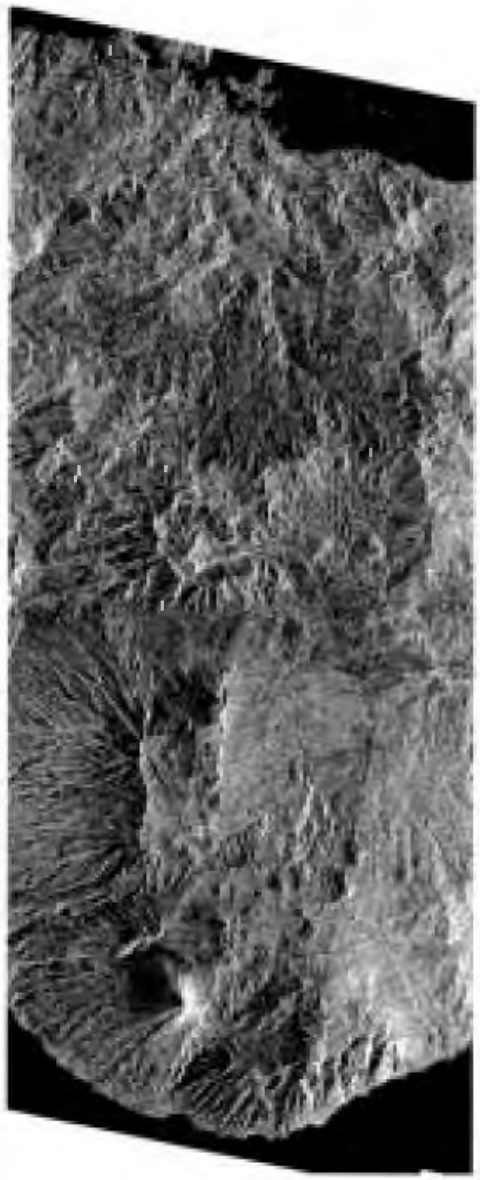

(ㅁ)

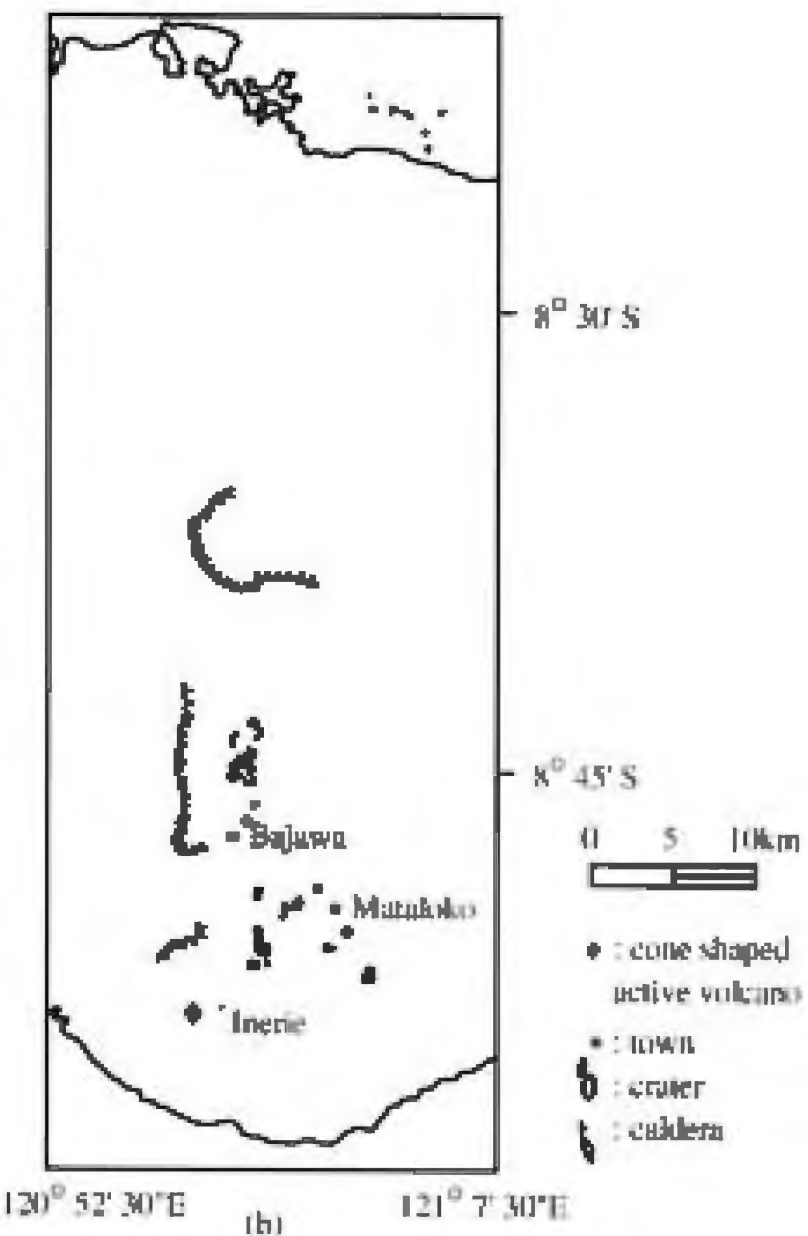

Fig. 3 SAR image analysis.

(a): JERS-1 SAR image taken on February 3, 1996 (Copyright METI/NASDA).

(b): volcanic terrain analyzed from a SAR image.

seen in the SAR image, especially in the southern coast. Figure 3 shows the SAR image of the study area taken on February 3, 1996. Many small volcanic cones, which have diameters less than $5 \mathrm{~km}$, are seen near Bajawa in the SAR image. Some volcanic cones are aligned along the north-south direction. Mt. Inerie is an active volcano located $13 \mathrm{~km}$ west of Mataloko. The smooth texture of the SAR image distinguishes younger volcanic sediments near Bajawa and Mataloko from older parts.

\subsection{JERS-1 OPS image}

Figure 4 is the mosaic of two OPS images for the study area taken on October 13, 1994 and July 9, 1998. The high elevation areas are red in the OPS image indicating dense vegetation. Soil and rice fields are observed as bright and dark colors, respectively. It suggests that there is much rain in the mountain areas on Flores Island. Volcanic features are not as obvious in the OPS image compared with the SAR image. Topographic analysis is difficult using OPS images with high sun elevation angles of 69 degrees for the eastern part and 53 degrees for the western. Vegetation anomalies are observed as a bright color in the OPS image. Sometimes geothermal activities cause vegetation anomalies. The field surveys are necessary to determine if the vegetation anomaly is caused by geothermal activities.

\subsection{ASTER VNIR image and digital terrain model generation}

The Advanced Spaceborne Thermal Emission and Reflection Radiometer (ASTER), which was launched on the Terra platform on December 18, 1999, is a high spatial resolution imaging spectro-radiometer consisting of Visible to Near-infrared Radiometer (VNIR), ShortWave-Infrared Radiometer (SWIR) and Thermal Infrared Radiometer (TIR). The ground resolution of VNIR, SWIR and TIR are $15 \mathrm{~m}, 30 \mathrm{~m}$ and $90 \mathrm{~m}$, respectively. The baseline performance requirements of ASTER are shown in Table 2. Yamaguchi et al. (1998) and Fujisada et al. (1998) describe about ASTER in detail.

Figure 5a shows an ASTER VNIR image of the study area acquired on July 16, 2001. This image is 


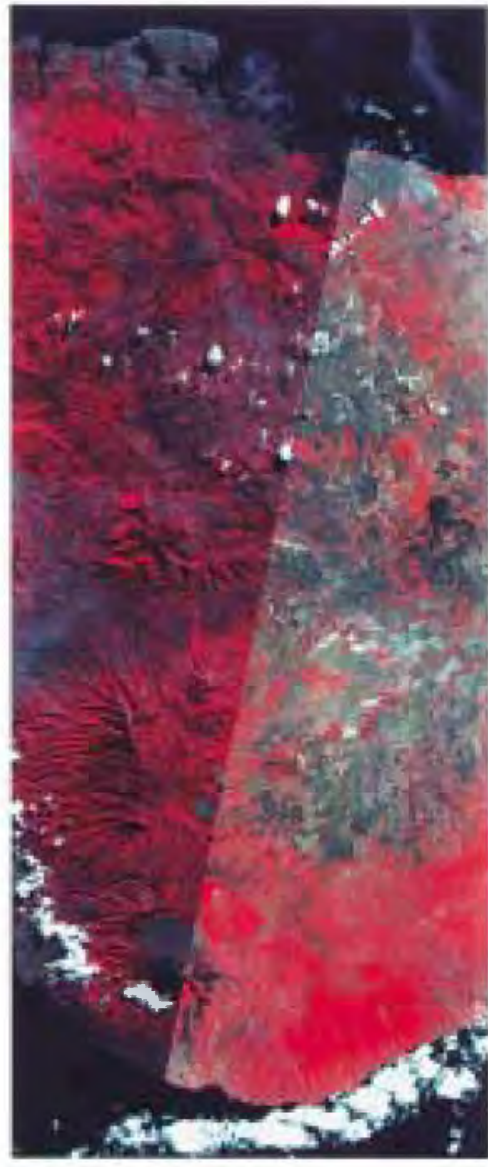

(i)

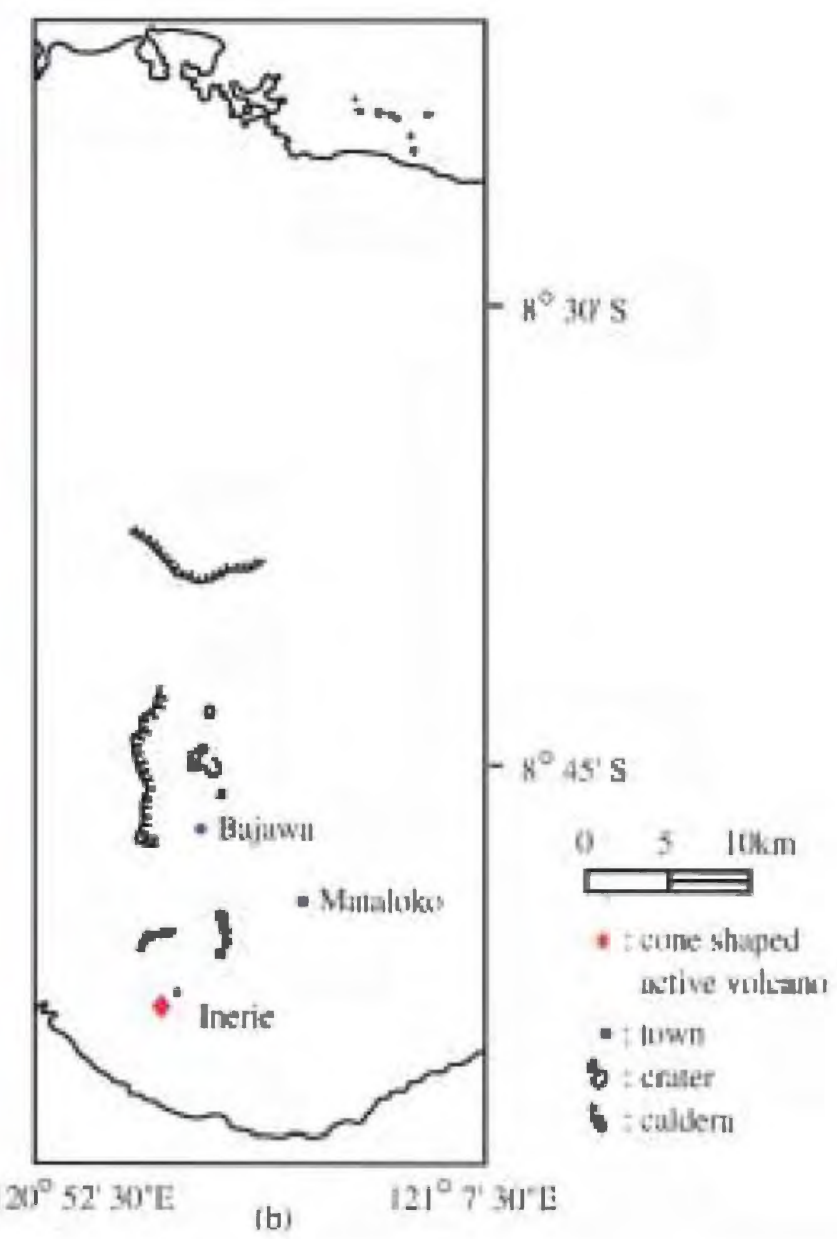

Fig. 4 OPS image analysis.

(a): the mosaic of two JERS-1 OPS images taken on October 13, 1994 (east) and July 9, 1998 (west) (Copyright METI/NASDA). The bands 3, 2 and 1 are assigned to red, green and blue, respectively.

(b): volcanic terrain analyzed from an OPS image.

covered by many small clouds and not adequate for geological interpretations. However, ASTER observes this area several times from August 2000 to the present (September 2001), this is the image of minimum cloud cover. Areas covered by vegetation are red. Soil and rice fields are seen as bright and dark colors, respectively, in the image, the same as JERS-1 OPS images.

The ASTER has one backward-viewing telescope for stereoscopic observation in the along-track direction to generate digital terrain models. Figure $5 \mathrm{~b}$ shows the digital terrain model generated from ASTER. In the middle of the study area, terrain data was not generated because of clouds and their shadows. Figure $6 \mathrm{a}$ shows the details of the digital terrain model around Mt. Inerie. The topography is quite similar to the existing topographic map (Fig. 6b) except for a false peak in the shadow area on the southern flank of Mt. Inerie. Height and geolocation accuracy of the digital terrain model generated from ASTER are approximately $10 \mathrm{~m}$ and 50 $\mathrm{m}$, respectively, without ground control point correction (Fijisada et al., 2001).

\subsection{ASTER TIR image}

Four partly clouded ASTER TIR scenes, from which we can detect a surface temperature anomaly, were acquired in the study area during the day and night. Figure 7a, 7b, 7c and 7d show the brightness temperature distributions observed at 14:41UT (22:41 local time) on June 23, 14:35UT (22:35 local time) on July 2, 2001, 2:30UT (10:35 local time) on July 16, 2001 and 14:35UT (22:35 local time) on July 18, 2001, respectively. The brightness temperature, which is calculated by the inverse of Plank's function without surface emissivity and atmospheric effects, is different form absolute surface temperature. However we can detect a surface temperature anomaly form the brightness temperature distribution. In the day time image (Fig. 7c), sun illumination effects are dominant. On the other hand, night time images are more suitable to detect surface temperature anomalies caused by geothermal activities because there are no sun illumination effects during the night 
Table 2 ASTER baseline performance requirements (modified from Yamaguchi et al. 1998).

\begin{tabular}{|c|c|c|c|c|}
\hline Subintem & Bund $\mathrm{Nu}_{0}$ & $\begin{array}{c}\text { Cedinal } \\
\text { Wavelenglat } \\
\text { (pm) }\end{array}$ & $\begin{array}{l}\text { Bind } \\
\text { Width } \\
\text { (itm) }\end{array}$ & $\begin{array}{c}\text { Sphtiv } \\
\text { Renolition } \\
\text { (m) }\end{array}$ \\
\hline \multirow{3}{*}{ VNIR } & $\mathbf{I}$ & 056 & 00 & \multirow{3}{*}{15} \\
\hline & 2 & 0.66 & 006 & \\
\hline & ] & 0.51 & 0. 10 & \\
\hline \multirow{6}{*}{ SWIR } & 4 & 1650 & 0.10 & \multirow{6}{*}{30} \\
\hline & 5 & 2165 & 004 & \\
\hline & 6 & $2.20,1$ & 0,04 & \\
\hline & 7 & 2260 & 0.05 & \\
\hline & 8 & 2330 & 0.07 & \\
\hline & 5 & 2395 & 0.07 & \\
\hline \multirow{5}{*}{$\mathrm{TIR}$} & 10 & $\$ .30$ & 0.35 & \multirow{5}{*}{90} \\
\hline & 11 & 8.65 & 0.35 & \\
\hline & 12 & 910 & 0.35 & \\
\hline & 13 & {$[0.60$} & 0.70 & \\
\hline & 14 & 11.30 & 070 & \\
\hline
\end{tabular}

\begin{tabular}{|c|c|}
\hline Steren Base-10-Height ruto & 0.6.6 \\
\hline Swinh width & (9) $\mathrm{km}$ \\
\hline $\begin{array}{l}\text { Tatal Cowerage in Crot-Trate Diretign by } \\
\text { Ponting }\end{array}$ & $232 \mathrm{~km}$ \\
\hline 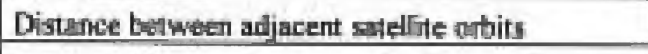 & $172 \mathrm{~km}$ \\
\hline Repear ejele & 16 days \\
\hline
\end{tabular}

time. Generally, the sea surface temperature is higher than land surface temperature during the night time, sea areas are red color that indicates a relatively high temperature in Figs. $7 \mathrm{a}, 7 \mathrm{~b}$ and $7 \mathrm{~d}$. The surface temperature of the land area depends on the elevation, and then we can found low temperature areas at high elevation. Clouds cause time-dependent low temperature anomalies, therefore low temperature anomalies that appeared only on one scene may be caused by the cloud effect. Low temperatures anomalies located in the southern part of Fig. 7b are not seen on other scenes, they are probably anomalies caused by clouds.

A small high temperature anomaly is found at the Nage geothermal area approximately $6 \mathrm{~km}$ east of Mt. Inerie in all temperature distribution images (Fig. 7). It's more obvious in the close-up view (Fig. 8). The anomaly extends $500 \mathrm{~m}$ west-east and $180 \mathrm{~m}$ north-south, which is same size as the Nage steaming field (Takahashi et al., 2000), and is up to 2.5 ${ }^{\circ} \mathrm{C}$ higher than the surrounding area. The temperature anomalies related to Mataloko and other geothermal areas are not found. Temperature differences between Bajawa and Nage area outside of the geothermal area were $3-8{ }^{\circ} \mathrm{C}$.

\section{In-situ surface temperature monitoring at the Nage geothermal area}

In-situ surface temperature monitoring was conducted from July 15 - 21, 2001 at the Nage geothermal area to validate the thermal anomaly detected by ASTER. During this period, which is the dry season, it was fine with some clouds and little rain. Four thermometers (Model TR-52 manufactured by T\&D Corporation) were set in the Nage geothermal area as shown in Fig. 9. However, one thermometer (Nage-4) was lost. One thermometer (Nage-1) was set at a farm approximately $100 \mathrm{~m}$ from the Nage geothermal area. Another thermometer was set in the backyard of the Ariesta Hotel in Bajawa. The location of the thermometers is in Table 3. These thermometers recorded surface or river water temperatures every minute.

Figure 10 shows the temperature changes from July 15 - 21, 2001. The water temperature of the Wae Bana River (Nage-3) was almost constant 73.4

${ }^{\circ} \mathrm{C}$. Temperature just outside of the Nage geothermal area (Nage-1) was lower than the temperature in the Nage geothermal area (Nage-2 and Nage-5) except for the nights of July 15 th and 16th. The temperature in Bajawa was $8-14{ }^{\circ} \mathrm{C}$ lower than the Nage area at 21:00 during this period.

The ASTER observed the study area both day time and night time during the surface temperature monitoring period. Because night time images are more suitable to detect surface temperature anomalies caused by geothermal activities, we concentrated our analysis on the night time image. Table 4 shows comparisons of brightness temperature derived from ASTER TIR band 13 and surface temperature measured by a thermometer on July 18 th. The temperature anomaly, the temperature difference between the inside and outside of the Nage geothermal area, is $1.5{ }^{\circ} \mathrm{C}$. However, brightness temperature difference between the two is $0.4{ }^{\circ} \mathrm{C}$. The in-situ and brightness temperature differences between Bajawa and Nage -1 is $9.5^{\circ} \mathrm{C}$ and $2.1{ }^{\circ} \mathrm{C}$, respectively. The atmosphere sometimes decreases the surface temperature difference, so the actual thermal anomaly may larger than the thermal anomaly derived from the brightness temperature distribution.

\section{Conclusions}

A remote sensing survey was conducted in the Ngada District for geothermal exploration using JERS-1 SAR and OPS, and ASTER VNIR and TIR data. As a result, many small volcanic cones, which have diameters less than $5 \mathrm{~km}$, are seen near Bajawa in the SAR image. Some volcanic cones are aligned along the north-south direction. Volcanic 


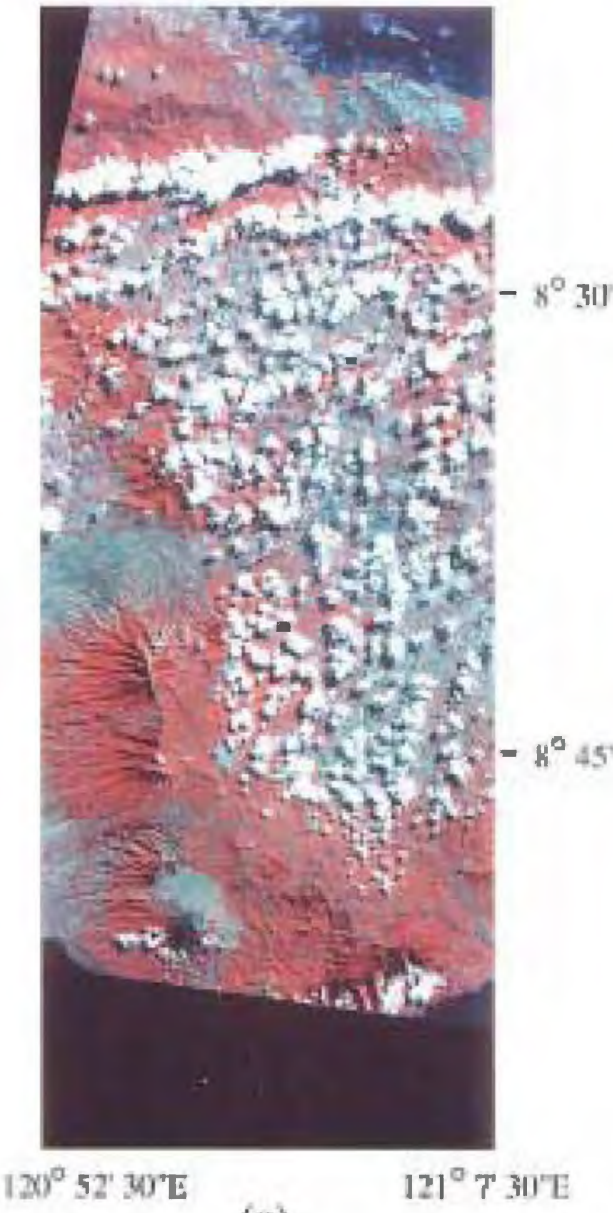

(a)

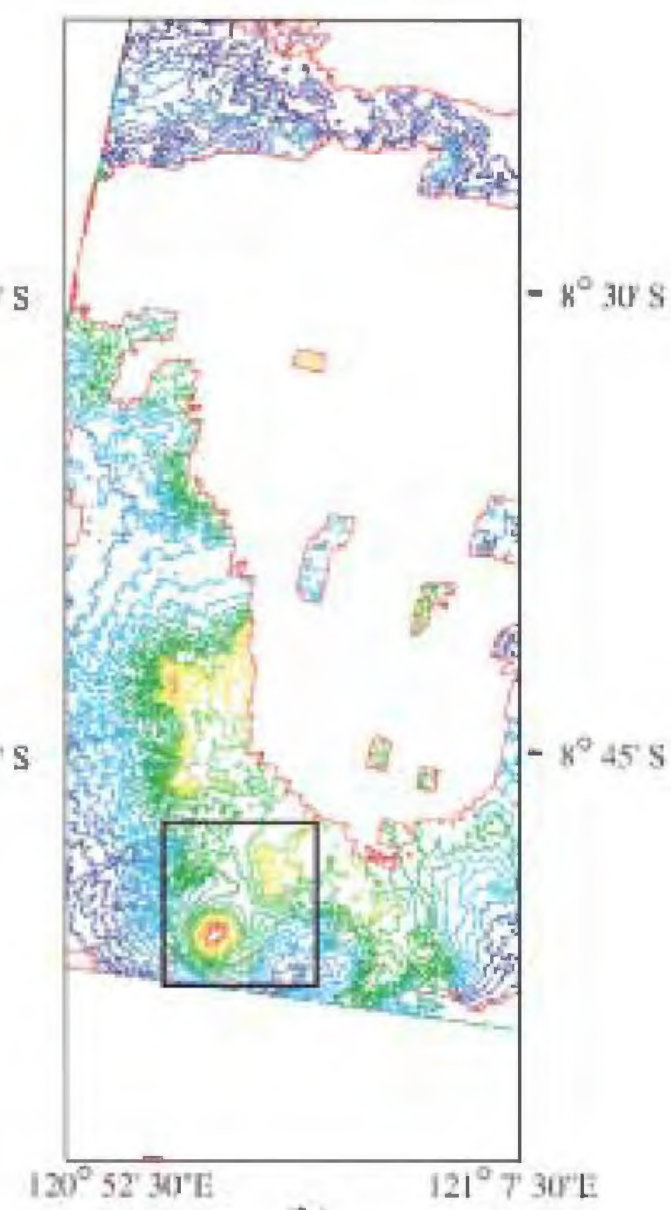

(b)

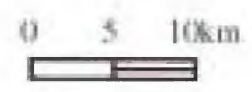

Fig. 5 VNIR image and digital terrain model.

(a): ASTER VNIR image taken on July 16, 2001 (Copyright METI/NASA). The bands 3, 2 and 1 are assigned to red, green and blue, respectively.

(b): digital terrain model generated from an ASTER stereo pair image. Contour interval is $100 \mathrm{~m}$. A rectangle indicates the area in Fig. 6.

features are not as obvious in the OPS image compared with the SAR image because of the high sun elevation angle in tropical areas. A small high temperature anomaly, up to $2.5{ }^{\circ} \mathrm{C}$, is found in the Nage geothermal area that has large manifestations on the ASTER TIR images. However it is difficult to detect temperature anomalies related to geothermal areas that have small manifestations. Because of atmospheric effects, temperature anomalies derived from the brightness temperature distribution may underestimate the actual temperature anomalies. These results demonstrate the advantages and limitations of satellite remote sensing survey for geothermal applications.

Acknowledgements: The authors wish to thank NASDA and METI/ERSDAC for providing JERS-1 and ASTER data. The authors are grateful to
ERSDAC for allowing the use of their computer facilities to generate digital terrain models for the authors. The authors thank Mr. Isao Sato of the Geological Survey of Japan, AIST for helpful comments on the manuscript.

\section{References}

Fujisada, H., Iwasaki, A. and Hara, S. (2001) ASTER stereo system performance. SPIE Proceedings, 4540, in press.

Fujisada, H., Sakuma, F., Ono, A. and Kudoh, M. (1998) Design and preflight performance of ASTER instrument protoflight model. IEEE Transactions on Geoscience and Remote Sensing; 36, 1152-1160.

Muraoka, H. and Uchida, T. (1999) Overview of 1998 investigations of the "Research Coope- 


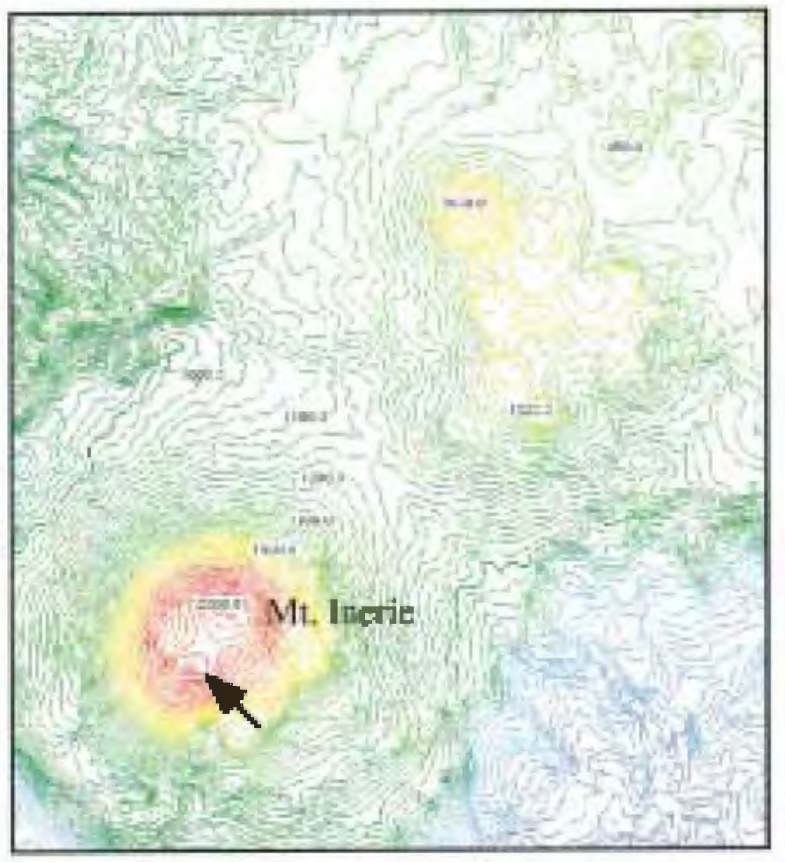

(a)

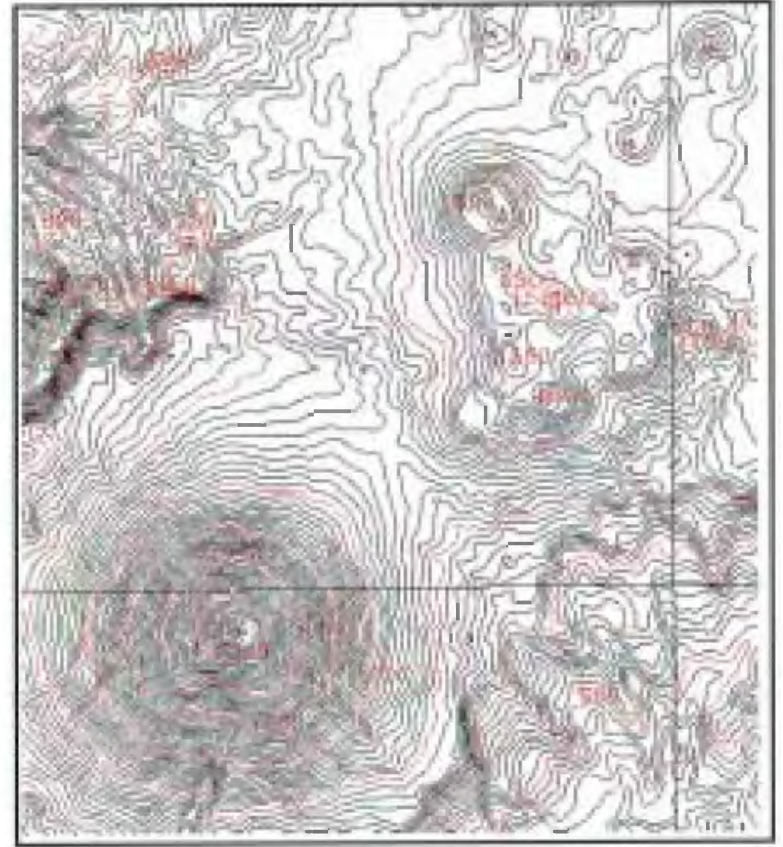

(b)

П $5 \mathrm{~km}$

Fig. 6 Digital terrain model near Mt. Inerie.

(a): digital terrain model generated from an ASTER stereo image pair on July 16, 2001. Contour interval is $25 \mathrm{~m}$. An arrow indicates the false peak.

(b): 25,000 : 1 topographic map. Keiji Tanaka, Hirofumi Muraoka and Masao Komazawa digitized from topographic maps at a scale of 1:25,000 in this project. Contouring was done by Masao Komazawa.

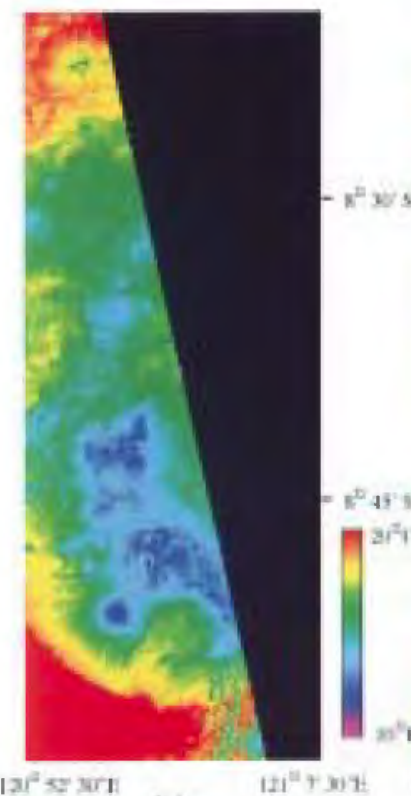

(u)

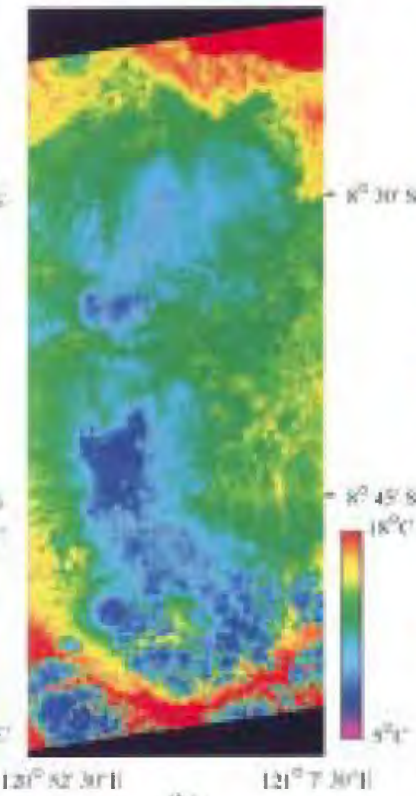

(b)

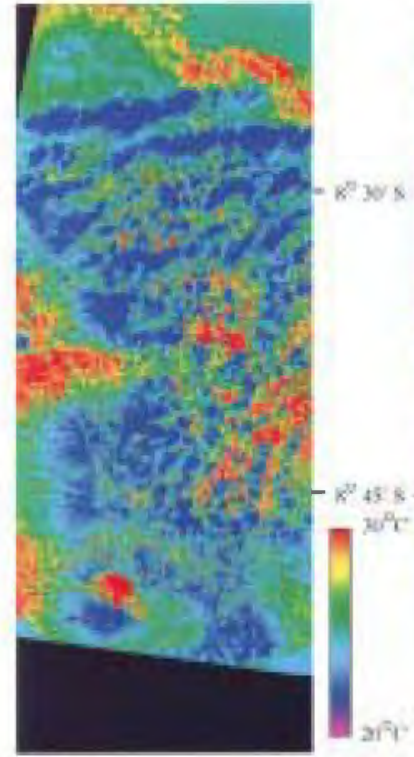

is!

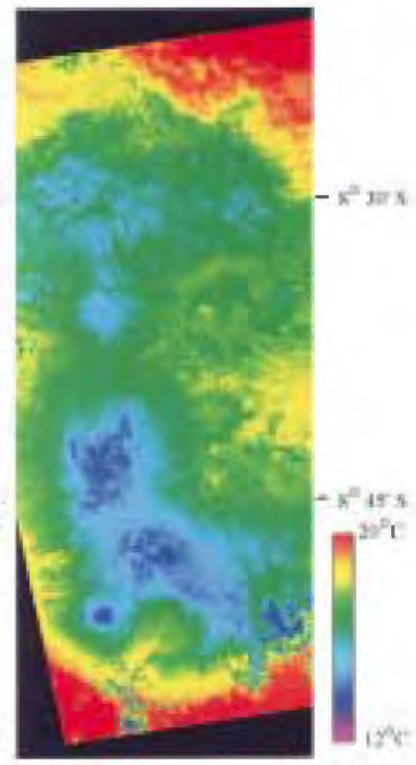

เป

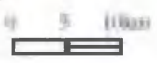

Fig. 7 Brightness temperature distribution of the study area derived from ASTER TIR band 13.

(a): 14:41UT (22:41 local time) on June 23, 2001.

(b): 14:35UT (22:35 local time) on July 2, 2001.

(c): 2:30UT (10:35 local time) on July 16, 2001.

(d): 14:35UT (22:35 local time) on July 18, 2001. 

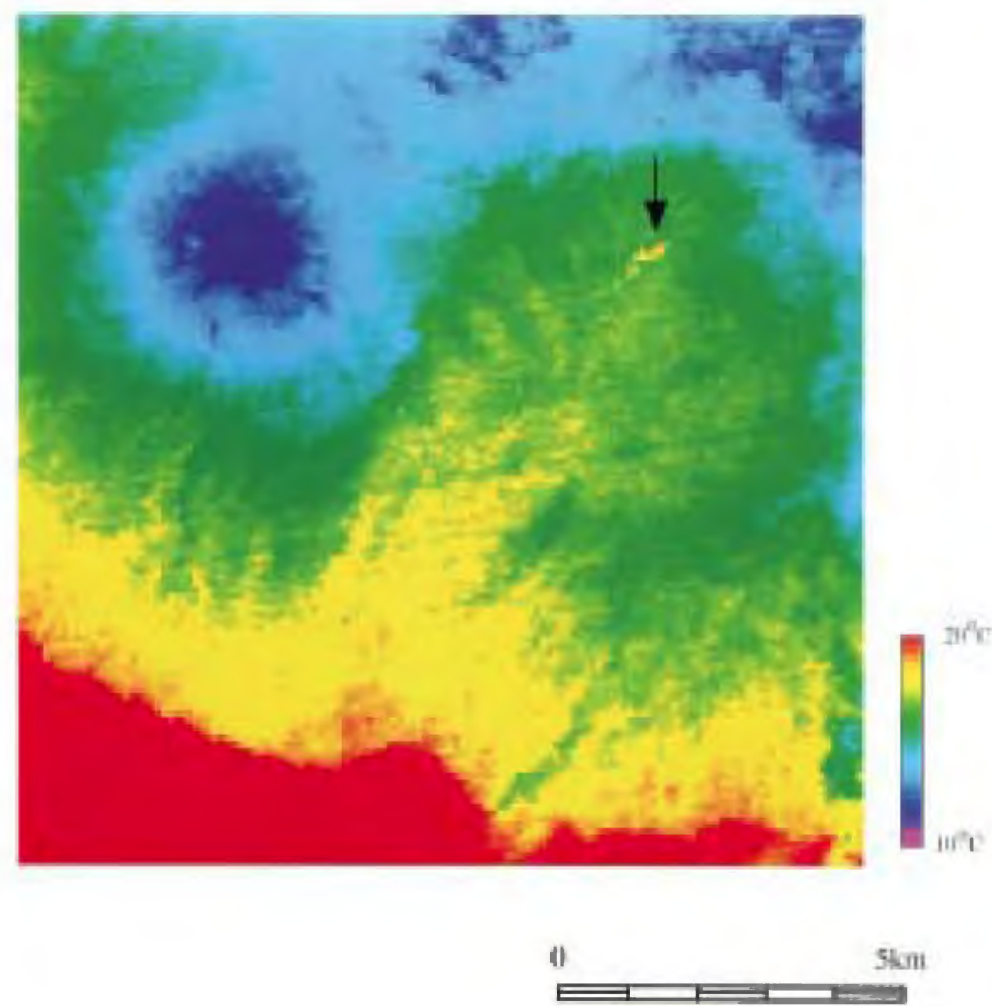

Fig. 8 Brightness temperature distribution of the southern Ngada District derived from ASTER TIR band 13 observed on June 23, 2001.

An arrow indicates the Nage geothermal area.

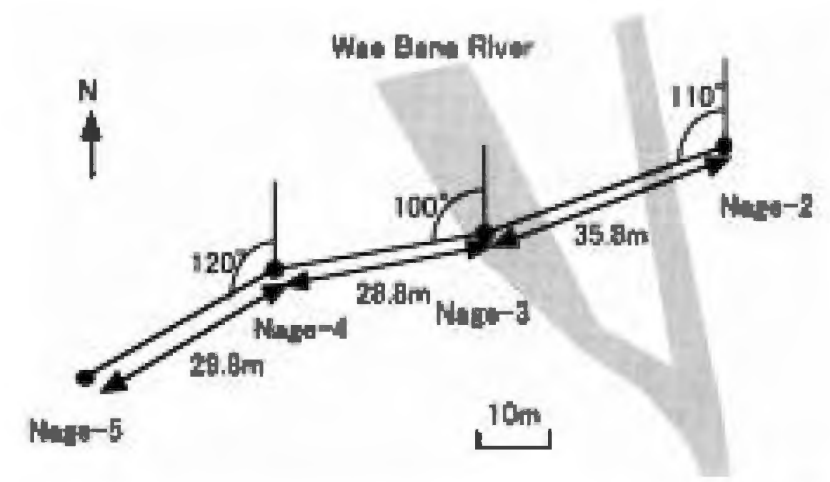

Fig. 9 Thermometer locations in the Nage geothermal area. Solid circles indicate the location of thermometers. The hatched area is Wae Bana River. The position of Nage-4 is $8^{\circ} 52.685^{\prime} \mathrm{S}$ and $120^{\circ} 0.654^{\prime} \mathrm{E}$ measured by GPS.

Table 3 List of thermometer locations measured by GPS. The coordinate system is WGS84.

\begin{tabular}{|c|c|c|c|c|}
\hline Fou ID & Loniade & Lale ind & Elerxian & Yois \\
\hline Byme & $k^{\prime}+4+w^{2} 5$ & 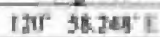 & $1217 n$ & Arien Hotel Eyont \\
\hline Mapt-1 & 85270015 & $121^{\prime} 0.526 \mathrm{E}$ & $\mathrm{ITI}=$ & 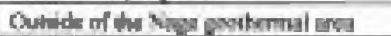 \\
\hline Nagx -2 & - & - & - & 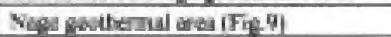 \\
\hline Nues-3 & . & $\overline{-}$ & - & 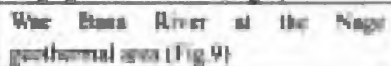 \\
\hline Naye-1 & 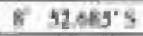 & $|2|^{\circ}$ UBSEE & 5300 & we \\
\hline Mape 5 & + & - & - & 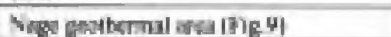 \\
\hline
\end{tabular}




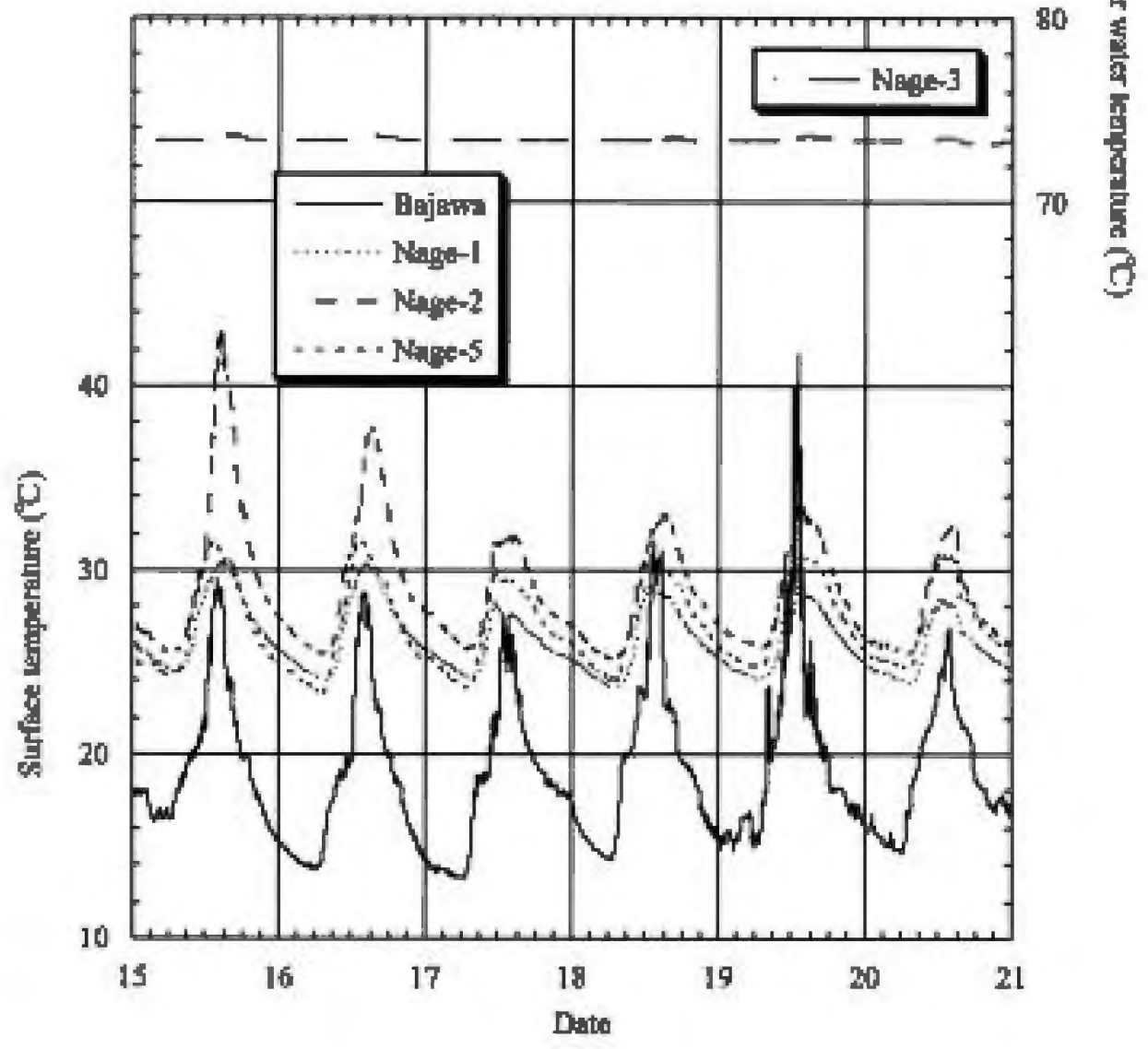

Fig. 10 Surface temperature changes in the Nage geothermal area from July $15-21,2001$.

Table 4 Comparisons of brightness temperature derived from ASTER TIR band 13 and surface temperature measured by thermometers at 14:35UT (22:35 local time) on July 18, 2001.

\begin{tabular}{|c|c|c|}
\hline Ruilat ID & 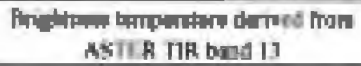 & 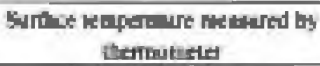 \\
\hline Bบ그ำ & []][$. & $|\boldsymbol{n}| \mathbb{C}$ \\
\hline 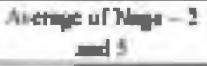 & $16.1 \mathrm{C}$ & $27.1 \mathrm{C}$ \\
\hline Ning롤 $=1$ & IS.T ᄃ & thin $\mathrm{C}$ \\
\hline
\end{tabular}

ration Project on the Exploration of Smallscale Geothermal Resources in the Eastern Part of Indonesia" by the Geological Survey of Japan. 1998 Interim Report, Research Cooperation Project on the Exploration of Small-scale Geothermal Resources in the Eastern Part of Indonesia, GT/99/1, Geological Survey of Japan, Tsukuba, 1-8.

Muraoka, H., Nasution, A., Urai, M., Takahashi, M. and Takashima, I. (1999) Regional geothermal geology of the Ngada District, central Flores, Indonesia. 1998 Interim Report, Research Cooperation Project on the Exploration of Small-scale Geothermal Resources in the Eastern Part of Indonesia, GT/99/1, Geological Survey of Japan, Tsukuba, 17-46.
Takahashi, M., Urai, M., Yasukawa, K., Muraoka, H., Matsuda, K., Akasako, H., Koseki, T., Hisatani, K., Kusnadi, D., Sulaeman, B. and Nasution, A. (1999) Geochemistry of hot spring waters at Bajawa area, central Flores, Nusa Tenggara Timur, east Indonesia - The report of geochemical researches for fiscal 1997 and 1998 -. 1998 Interim Report, Research Cooperation Project on the Exploration of Small-scale Geothermal Resources in the Eastern Part of Indonesia, GT/99/1, Geological Survey of Japan, Tsukuba, 47-58.

Takahashi, M., Urai, M., Yasukawa, K., Muraoka, H., Matsuda, K., Akasako, H., Koseki, T., Hisatani, K., Kusnadi, D., 
Sulaeman, B. and Nasution, A. (2000) Geochemistry of hot spring waters at Bajawa area, central Flores, Nusa Tenggara Timur, Indonesia - The report of geochemical researches for fiscal 1999 -. 1999 Interim Report, Research Cooperation Project on the Exploration of Small-scale Geothermal Resources in the Eastern Part of Indonesia, GT/00/2, Geological Survey of Japan, Tuskuba, 31-46.

Takata, N.(1995) SAR / OPS characteristics and status. Final Rep. JERS-1/ERS-1 System Verification Program, MITI/NASDA, Tokyo, $1,9-14$

Urai, M., Muraoka, H. and Nasution, A. (1999) Remote sensing imagery of promising geothermal fields in the Nusa Tenggara, Timur, Indinesia. 1998 Interim Report, Research Cooperation Project on the Exploration of Small-scale Geothermal Resources in the Eastern Part of Indonesia, GT/99/1, Geological Survey of Japan, Tsukuba, 9-16.

Urai, M., Muraoka, H. and Nasution, A.(2000)
Remote sensing study for geothermal development in the Ngada District, central Flores, Indonesia. Proceedings of the World Geothermal Congress 2000, Beppu, Japan, 1905-1908.

Yamaguchi, Y., Hase, H. and Ogawa, K. (1992a) Remote sensing for geothermal applications. Episodes, 15, 62-67.

Yamaguchi, Y., Tsu, H., Urai, M., Sato, I. and Miyazaki, Y. (1992b) Preliminary investigation on JERS-1 users' performance requirements using image data. Journal of the Remote Sensing Society of Japan, 12, 343348. (in Japanese with English abstract).

Yamaguchi, Y., Kahle, A. B., Tsu, H., Kawakami, T. and Pniel, M. (1998) Overview of Advanced Spaceborne Thermal Emission and Reflection Radiometer (ASTER). IEEE Transactions on Geoscience and Remote Sensing, 36, 1062-1071.

Received September 14, 2001

Accepted February 21, 2002

\title{
地熱応用のための衛星リモートセンシングデータとその解釈 : \\ インドネシア, 中央フローレス, ンガタ地域におけるケーススタディ
}

浦井 稔・村岡洋文・Asnawir NASUTION

\begin{abstract}
要旨
ンガ夕地域において地熱資源探查を目的として，JERS-1 の SAR， OPS おょび ASTER VNIR, TIR を用いたリモートセンシング調查を実施した。そこの結果, 多数の直径 $5 \mathrm{~km}$ 以下の火山冈錐丘が バジャワ付近の SAR 画像に見られた。 その内のいくつかは南北方向に並んでいる. SAR は全天候性 の観測能力があるため, 光学センサによって雲の無い画像を撮影することが難しい当該地域においても 火山の特徵を詳細に捉えることができた。一方，太陽高度が高かったため，OPS 画像では SAR 画像 に比較して火山の特徴を捉えることは難しかった。近年打ち上げられた新しい高空間分解能センサであ るASTER TIR によってナゲ地熱地域の熱異常が捉えられた。これらの結果は地熱応用における衛星 リモートセンシング調查の有用性と限界を実証するあのである。
\end{abstract}

